\title{
You are not a man, none of you are men! Early Christian masculinity and Lucian's the Passing of Peregrinus
}

\begin{tabular}{|c|c|}
\hline $\begin{array}{l}\text { Author: } \\
\text { Eric Stewart }^{1,2}\end{array}$ & \\
\hline $\begin{array}{l}\text { Affiliations: } \\
{ }^{1} \text { Department } \\
\text { Augustana Co } \\
\text { Island, United }\end{array}$ & $\begin{array}{l}\text { Religion, } \\
\text { lege, Rock } \\
\text { States }\end{array}$ \\
\hline $\begin{array}{l}{ }^{2} \text { Department } \\
\text { Testament anc } \\
\text { Literature, Fac } \\
\text { Theology and } \\
\text { University of P } \\
\text { Pretoria, Sout }\end{array}$ & $\begin{array}{l}\text { f New } \\
\text { Related } \\
\text { ulty of } \\
\text { Religion, } \\
\text { retoria, } \\
\text { h Africa }\end{array}$ \\
\hline $\begin{array}{l}\text { Research Proj } \\
\text { Project Leade } \\
\text { Project Numb }\end{array}$ & $\begin{array}{l}\text { ect Registration: } \\
\text { r: E. van Eck (D) } \\
\text { er: } 2400030\end{array}$ \\
\hline $\begin{array}{l}\text { Description: } \\
\text { Prof Stewart is } \\
\text { in the researcl } \\
\text { 'Hermeneutic } \\
\text { directed by Pr } \\
\text { van Eck, Depa } \\
\text { Testament anc } \\
\text { Literature, Fac } \\
\text { Theology and } \\
\text { University of P }\end{array}$ & $\begin{array}{l}\text { partcipating } \\
\text { project } \\
\text { and Exegesis' } \\
\text { of. Dr Ernest } \\
\text { tment of New } \\
\text { Related } \\
\text { ulty of } \\
\text { Religion, } \\
\text { retoria. }\end{array}$ \\
\hline $\begin{array}{l}\text { Correspondin } \\
\text { Eric Stewart, } \\
\text { estewart40@g }\end{array}$ & gauthor: \\
\hline $\begin{array}{l}\text { Dates: } \\
\text { Received: } 10 \mathrm{~J} \\
\text { Accepted: } 13 \\
\text { Published: } 24\end{array}$ & $\begin{array}{l}\text { une } 2019 \\
\text { ep. } 2019 \\
\text { Oct. } 2019\end{array}$ \\
\hline $\begin{array}{l}\text { How to cite th } \\
\text { Stewart, E., } 20 \\
\text { not a man, no } \\
\text { men! Early Ch } \\
\text { masculinity an } \\
\text { Passing of Per } \\
\text { Teologiese Stu } \\
\text { Theological St } \\
\text { a5609. https:/ } \\
10.4102 / \text { hts.v }\end{array}$ & $\begin{array}{l}\text { is article: } \\
19, \text { 'You are } \\
\text { ne of you are } \\
\text { ristian } \\
\text { d Lucian's the } \\
\text { egrinus', HTS } \\
\text { dies/ } \\
\text { udies } 75(4), \\
\text { /doi.org/ } \\
75 \text { i4.5609 }\end{array}$ \\
\hline $\begin{array}{l}\text { Copyright: } \\
\text { (C) 2019. The A } \\
\text { Licensee: AOS } \\
\text { is licensed unc } \\
\text { Creative Comr } \\
\text { Attribution Lic }\end{array}$ & $\begin{array}{l}\text { uthors. } \\
\text { S. This work } \\
\text { ler the } \\
\text { nons } \\
\text { ense. }\end{array}$ \\
\hline Read online: & \\
\hline 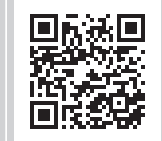 & $\begin{array}{l}\text { Scan this QR } \\
\text { code with your } \\
\text { smart phone or } \\
\text { mobile device } \\
\text { to read online. }\end{array}$ \\
\hline
\end{tabular}

Much recent work on the masculinities enacted by early Christians has focused upon Christian texts and claims about their heroes and practices among elite Christians. Lucian's Passing of Peregrinus offers another avenue for thinking about early Christian masculinity. Lucian denies Peregrinus' claim to masculinity on the basis of his over-concern for honour, especially from the masses, his inability to control his appetites regarding food and sex, his being a parricide, his enacting 'strange' ascetic practices and his lack of courage in the face of death. By tying Peregrinus to a Christian community in Judea, Lucian both demonstrates the lack of manliness in the Christian movement, which he suggests is populated mostly by gullible women and children, and further 'unmans' Peregrinus by linking him to a community of easily duped people whose praise is not worthy of a philosopher. By presenting this Christian community as a group that not only accepts Peregrinus as a member but also quickly establishes him as their leader, almost at par with Jesus himself, according to Lucian's account, these early Christians show their lack of self-control by being deceived by a charlatan. Early Christian writers who claimed that their heroes were manly, even more manly than the Greek or Roman heroes, were writing in part to rebut the types of claims made by writers like Lucian.

Keywords: Lucian; Peregrinus; Early Christianity; Masculinity; Honour.

It is my great privilege to contribute to this special issue of Hervormde Teologiese Studies (HTS) celebrating the 75th anniversary of the journal issued by the Faculty of Theology at the University of Pretoria and to celebrate the contributions of Maake Masango to their mission. The research conducted at the Faculty of Theology, together with the hospitality they have shown in hosting international scholars, is a cause for celebration both in South Africa and throughout the world. May they continue to provide a model for an engaged scholarship for those in their homeland and for those around the world.

\section{Introduction}

In a now two-decade-old book, Leon J. Podles (1999) argues that the church is being feminised.

Disparities in church attendance among men and women can be explained based on feminisation. Podles is clear that his book addresses the North American, Western European and Australian contexts (and most directly Catholicism). In these places, church attendance by men has been on the decline. Women, for a number of reasons according to Podles, are now in control of the churches (even as most are still led by men). Men's religion is masculinity (Podles 1999:xii). Moreover, it is non-masculine men who are more likely to attend churches (Podles 1999):

Because Christianity is now seen as a part of the sphere of life proper to women rather than to men, it sometimes attracts men whose own masculinity is somewhat doubtful ... men who are fearful of making the break with the secure world of childhood dominated by women. (p. xiv)

Whatever one makes of Podles' arguments and that there is no room to respond to them with any type of seriousness here, the idea that Christianity represents something feminine is far older than the 20th century. From the inception of the Jesus movement, followers of Jesus have been derided as unmanly. In fact, the specific combination of children and women as dominant among Christians that Podles claims is a trope at least as old as the 2nd century. These accusations of unmanliness provoked responses by Christians who sought to portray Jesus and his followers as demonstrating masculine virtues or as practising an alternative masculinity sanctioned by a powerful male deity.

Scholars have produced numerous works on masculinity in early Christianity in the last several decades (for descriptions of many of these works and the current state of the field in this area,

Note: HTS 75th Anniversary Maake Masango Dedication. 
see Stewart 2016b:91-102, 2018:n.p.). One of the points of contestation in these studies is the extent to which early Christians mimicked or practised the dominant Greek and Roman masculinities. Much of this work has been conducted in light of Connell's notion of hegemonic masculinity. This notion, first developed by Carrigan, Connell and Lee (1985:551-604), stresses that masculinities exist in relational terms (Connell 2005:67-86). Carrigan et al. (1985) describe a variety of relational masculinities, including hegemonic, complicit, subordinate and marginalised masculinities, and others have put these concepts to use for understanding various early Christian texts (Asikainen 2018:1-18; Stewart 2015:1-9, 2016a:1-7). Hegemonic masculinity is the form of masculinity which is dominant in any given culture at any given time (Connell \& Messerschmidt 2005:830-833; Levy 2007:832-33). According to Levy (2007:254), hegemonic masculinity can refer to: '(1) a position in the system of gender relations; (2) the system itself; and (3) the current ideology that serves to reproduce masculine domination'. In this way, hegemonic masculinity can refer to the male(s) at the top of the hierarchical system, the patriarchy itself that keeps some man or men dominant over most men and over women or the particular features of masculinity valued in a particular culture at a particular time. Most of the Western history is marked clearly by patriarchy, but the particular elements considered 'manly' change from time to time and from place to place. These elements relegate some men to the status of 'marginalised' masculinities. 'Marginalization is always relative to the authorization of the hegemonic masculinity of the dominant group' (Connell 2005:80-81). Connell provides an example of the way that black masculinities in American culture 'play symbolic roles for white gender construction' (Connell 2005:80). According to Levy (2007:254), men in subordinated positions 'possess the necessary physical attributes to aspire to hegemony' but they 'run the risk of subordination when they do not practise gender consistent with the hegemonic system and ideology'.

Most men, including some whose masculinity is subordinated or marginalised, practise complicit masculinity (Levy 2007):

These men accept and participate in the system of hegemonic masculinity so as to (1) enjoy the material, physical and symbolic benefits of the subordination of women, (2) through fantasy experience the sense of hegemony and learn to take pleasure in it, and (3) avoid subordination. (p. 254)

Even a man in a subordinate position (for Connell [2005], a homosexual man is a primary example in modern western cultures) might enact complicity with hegemonic masculinity in order to enjoy the benefits that come with being a man in a patriarchal society. Connell (2005:81) summarises this theory by suggesting 'that terms such as "hegemonic masculinity" and "marginalized masculinities" name not fixed character types but configurations of practices generated in particular situations in a changing structure of relationships'. For this reason, the ways in which men and women relate to 'hegemonic masculinity' and the continuation of any type of masculine ideology and enactment as 'hegemonic' are regularly contested. One of the main questions regarding early Christian masculinity is whether early Christian masculinities are hegemonic, complicit, marginalised or voluntarily subordinate (Conway 2017:17-27; Wilson 2017:28-48). Different groups of Christians positioned themselves differently regarding hegemonic masculinity (Stewart 2015:1-9, 2016b:1-7).

Cobb (2012:esp. 1-32) uses the Social Identity Theory for understanding how early Christians framed stories about martyrs in the light of potential critique from Romans about the masculinity of Christians. In so doing, she describes a range of measures that early Christians used to rebut critique that they were, by their very participation in a movement devoted to a crucified saviour, unmanly. The notion that Jesus himself was perceived as unmanly because of his crucifixion made his followers, by extension, unmanly in the eyes of hegemonic Greek and Roman ideals in the 1st and 2nd centuries of the Common Era (Conway 2008:3-14; Gleason 2003:325-327). From a Roman point of view, then, early Christians practised a marginalised form of masculinity (Asikainen 2018:184-87). For Cobb, however, instead of accepting the verdict that early Christians were unmanly because they were executed, the martyrdom tales framed Christians as enacting a superior masculinity, 'a masculinity that pagans, Jews, and Christian apostates, to differing degrees, lacked' (Cobb 2012:6). By depicting their heroes as (Cobb 2012):

[G]ladiators, athletes, and soldiers ... the texts illustrate Christian masculinity by the favorable juxtaposition of types of individuals who would have been expected to be unmanly (e.g. women, young or old men, slaves) with those at the height of masculinity (the governor or pronconsul). (p. 7)

Importantly, the stories of early Christian female martyrs 'underscored the superiority of Christian masculinity: even Christian women were manlier than their male persecutors' (Cobb 2012:126).

Early Christians, however, would not have told these stories in this way except for the fact that their ability to live up to ideals of masculinity was in question in the Roman world (see, e.g., Origen, Against Celsus 3.55).

A key text that links Christians with an unmanly hero is Lucian's The Passing of Peregrinus. Lucian clearly identifies Peregrinus as a charlatan, and also calls him a Christian, describing his affiliation with a Christian group in Palestine. In fact, it is characteristic of Christians, for Lucian, that they are easily duped by a charlatan like Peregrinus. His insufficient enactment of masculinity regarding his own 'noble death' is the distinguishing characteristic of Peregrinus for Lucian. But this lack of enacting a perfectly noble death is prefigured throughout the text, as Lucian informs the readers all along the way that Peregrinus is not masculine because of his love of honour, his lack of self-control regarding sexuality 
and eating, the fact that he killed his own father, his lack of magnanimity and his emotional display of fear at key moments in his life.

Preserved within the text of the Passing of Peregrinus is a contestation over Peregrinus' masculinity. Lucian seeks to marginalise Peregrinus' masculinity, although there are suggestions throughout the work that an alternative memory of Peregrinus, one that highlighted his endurance and bravery, his death for others and his magnanimity, linked Peregrinus to a masculinity that exhibited full self-control, not unlike other well-known philosophers and divine figures who preceded him. Even in death, Peregrinus' masculinity is not fully established and continues to be contested. Lucian's associating Peregrinus with groups that were considered unmanly, like Christians and Cynics, borrows from wellestablished tropes and contributes to his efforts to marginalise Peregrinus' masculinity.

\section{Masculinity in early Christianity}

Early Christians did not create notions of manliness from nothing. There were several competing notions of what it meant to be a man in the Roman world. Because of space constraints, we will consider here only two of these notions. Susanna Asikainen's recent book, Jesus and Other Men, details two ideal forms of masculinity in the Roman world (Asikainen 2018:19-45). Building upon and modifying Connell's model of relational masculinities, Asikainen argues that one ideal masculinity involved the domination of others, while another ideal masculinity involved demonstrating control over one's self. These two masculinities, although sometimes possibly embodied in the same person, often were portrayed as in tension with one another.

Asikainen (2018:4-5) focuses upon gender ideology, and she describes masculine ideology as 'the idea that a group has: what the ideal man is like, or how a man should behave'. Asikainen (2018:10) critiques Connell's work, arguing that more than one gender ideology might be in the hegemonic position, and 'the masculinities competing for the hegemonic position can have completely different ideals'. On this point, Asikainen incorrectly, in my view, critiques Connell. Connell is clear that masculinities are relational and that there can be competition for the hegemonic position. As Connell (2005:77-78) directly says, ' $[h]$ egemony, then, is a historically mobile relation. Its ebb and flow is a key element of the picture of masculinity proposed in this book' (see also my forthcoming review of Asikainen's book in Biblical Theology Bulletin 49.3).

That one type of masculinity is in the hegemonic position at any given time does not preclude competition from other masculinities for the position at the top of a hierarchy of masculinities. Moreover, in rethinking the concept of hegemonic masculinity, Connell and Messerschmidt (2005:851) note that ' $[i] \mathrm{t}$ is important not only that masculinities be understood as embodied but also that the interweaving of embodiment and social context be addressed'.

These two ways of enacting masculinity sat uneasily aside one another in Roman notions of what it meant to be masculine. On the one hand, to be a Roman vir meant to be dominant over others, women and men alike, accomplished in government and warfare, inviolable in terms of one's body and to demonstrate control over one's self (Parker 1997:47-65; Richlin 2007:265-267; Stewart 2016a:94-96; Walters 1997:29-43; Williams 2010:177-197). Martyrs and sometimes others facing death lacked such bodily inviolability but exhibited near-total control of the self in every other way (Cobb 2012:60-91, 2014:224-240; Moore \& Anderson 1998:249-273). What Asikainen does well to show, however, is that there is evidence of significant contestation among masculine ideologies in the ancient Roman world, and her understanding of masculine ideologies is useful for assessing Lucian's description of Peregrinus.

\section{The masculinity of Peregrinus}

Peregrinus, like any philosopher, is not expected to demonstrate the ideal form of masculinity that involves domination of other people, but philosophers (at least the most praiseworthy ones) were widely known for their selfcontrol, especially in the face of tyrants who could dominate them physically by imprisoning or killing them (Moore \& Anderson 1998:249-273). That Peregrinus, according to Lucian, lacked such self-control, as will be demonstrated below, moved him into the category of 'unmanly'. Moreover, that he was able to persuade a group of Christians to follow him makes, for Lucian, the whole movement unmanly. Although Lucian himself is unimpressed with Jesus' death, Peregrinus represents an emulation of Jesus that is even more unmanly. Not only is Peregrinus unable to undergo a noble death, those Christians who follow him are liable, according to Lucian, to replace following Jesus with following Peregrinus. Lucian counts on the notion that Christians are considered unmanly in order to further castigate Peregrinus' masculinity.

The story of Peregrinus opens with a summary of his death, occurring as he threw himself into a pyre after the Olympic games. This account is summarised from Lucian's perspective in sections $1-10$ of the book.

Following a brief speech by the Cynic Theagenes in copious praise of Peregrinus (4), Lucian relates a speech by an unnamed critic of Peregrinus (8-30) who is most certainly Lucian himself as the narrator (König 2006:227-254).

Theagenes had favourably compared Peregrinus, whom he calls Proteus, with Heracles, Asclepius, Dionysius and even Zeus (4-6). Furthermore, Theagenes claimed that Peregrinus donated an inheritance worth 5000 talents to his home city of Parium, got himself banished from the city of Rome on account of his philosophy, 'is more conspicuous than the sun' 
and 'is able to rival Olympian Zeus himself' (4). Clearly, Theagenes' speech was meant to honour the one he called 'Proteus' (6). The unnamed critic, whose speech follows Theagenes', claims:

I have observed his character and kept an eye on his career from the beginning, and have ascertained various particulars from his fellow-citizens and people who cannot have helped knowing him thoroughly. (Passing of Peregrinus 8)

Lucian's narrator's speech seeks to undo the praise and honour given to Peregrinus in the speech of Theagenes. The narrator concentrates especially on Peregrinus' concern for honour, especially from the masses, his lack of self-control in his sexual practices, his role as a parricide, his lack of magnanimity and his fear of death.

\section{Peregrinus is overly concerned with honour, especially from the masses}

As Downing makes clear, ancient Greeks and Romans were fully capable of recognising too much concern for honour, and they regularly used terms like 'vainglory' and 'hypocrisy' for describing it (Downing 1999:63-68). Lucian's description of Peregrinus throughout the Passing of Peregrinus is as a figure who seeks honour but is unable to attain true manliness because of his overwhelming desire for it:

After turning into everything for the sake of notoriety ( $\delta$ ó $\xi \eta \varsigma$

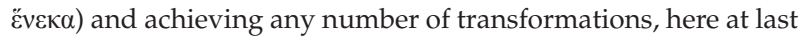
he has turned into fire; so great, it seems, was the love of notoriety

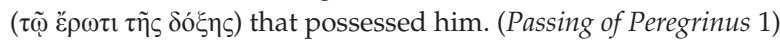

(1: all translations of this text, unless otherwise specified, are taken from Harmon in the Loeb Classical Library). Even in death 'this gentleman waited for that one of the Greek festivals which draws the greatest crowds' (1). Throughout the text, Lucian's narrator relates details of Peregrinus' life to his love of honour. When Peregrinus was imprisoned, the governor of Syria, recognising that Peregrinus 'would gladly die in order that he might leave behind him a reputation for

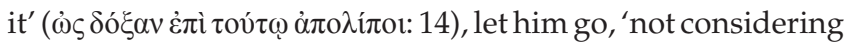
him worthy even of the usual chastisement' (14). This governor, according to the narrator, clearly saw through Peregrinus an attempt to use hostility from the governor as an opportunity to increase his reputation. A short time later, arriving in Italy, Peregrinus attempted to bait a 'mild and gentle' emperor into exiling or martyring him by verbally abusing the emperor (18). In spite of the emperor's lack of concern for Peregrinus' behaviour, 'even from this his

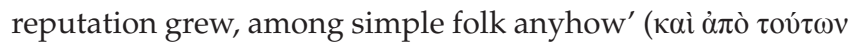

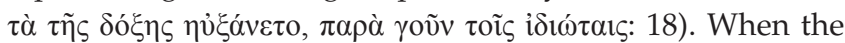
city prefect sent him away because he would not shut up, 'this too made for his renown ( $\kappa \lambda \varepsilon$ vòv), and he was on everybody's lips as the philosopher who had been banished

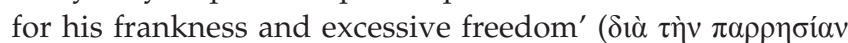

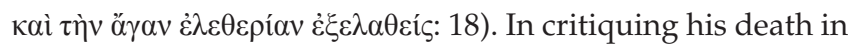
particular, Lucian suggests that he should have waited for death instead of hastening its arrival and certainly not have done it at the Olympic games because of the crowds (21), although at that point the narrator makes a joke about parricides and atheists deserving death by fire.

Of his wish to die in a holy place wherein one should not even be buried, the narrator attributes this to 'the craving for

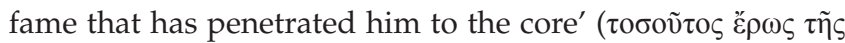

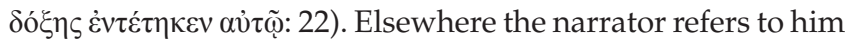
as 'a man so desperately in love with glory beyond all others

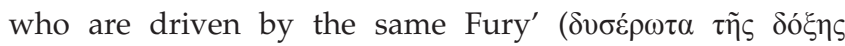

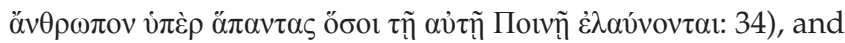
someone who 'always did and said everything with a view to

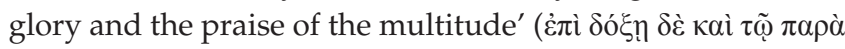

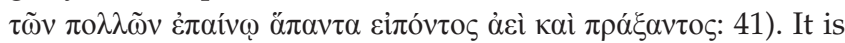
clear that Peregrinus' love of honour was problematic for the narrator.

\section{Lucian's sexual behaviour}

A second key problem for Lucian's narrator is Peregrinus' sexual behaviour. Among the details of his reputation that Lucian raises are that he was caught in the act of adultery and paid 3000 drachmas to the parents of a 'handsome boy' whom he had 'defiled' ( $\delta 1 \alpha \varphi \theta \varepsilon i p a \varsigma)$ to avoid 'being brought before the governor of the province of Asia' (9). Each incident lent itself to a judgement that Peregrinus lacked control of himself sexually.

Both of these incidents happened when Peregrinus had just

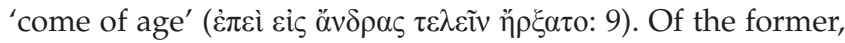
Lucian tells us that:

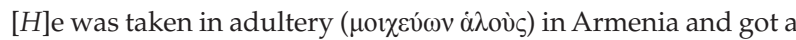
sound thrashing ( $\mu \alpha \dot{\lambda} \lambda \alpha \pi 0 \lambda \lambda \dot{\alpha} \varsigma \pi \lambda \eta \gamma \alpha \grave{\varsigma} \varsigma \bar{\varepsilon} \lambda \alpha \beta \varepsilon v$ ), but finally jumped down from the roof and made his escape, with a radish stopping

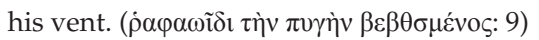

Putting a radish in a man's anus for committing adultery was a well-known punishment for adultery in the Greek world and continued into the Roman period (Glancy 2003:260). With respect to the 'defiling' of the 'handsome boy', Williams (2010:122-136) notes that both pederasty and adultery were of significant concern to moralists in the Roman period. Most significantly, these were accusations designed to undermine the praise of Peregrinus in the speech of Theagenes and were part of a standard invective against opponents in the Roman period (Williams 2010:111-112,118-122). Lucian does not tell us that Peregrinus was the penetrated partner in either of these sexual encounters, but, as Williams (2010) puts it:

A man might lose his grip on masculine control in various ways $\ldots$ by seeking to be dominated or even penetrated by his sexual partners, by subjugating himself to others for the sake of pleasuring or entertaining them, or by yielding to his own passions, desires, and fears. Masculinity was not fundamentally a matter of sexual practice; it was a matter of control. (p. 155)

By seeking illicit sexual partners, Peregrinus clearly acted outside the bounds of masculine decorum. 


\section{Other challenges to Peregrinus' masculinity}

Another significant challenge to Peregrinus' masculinity, according to the narrator, was that he committed parricide by strangling his father so that he would not age beyond 60 years. Duties towards one's parents, a part of the concept of piety in the Graeco-Roman world, rendered parricide among the most horrific acts one could commit (Asikainen 2018:29-31; D'Angelo 2003:66-71). After the incident 'had been noised abroad, he condemned himself to exile and roamed about, going to one country after another' (Passing of Peregrinus 10). For Lucian, Peregrinus had no choice but to leave home after this shameful act. When he returned to Parium later in the account, 'the people themselves were enraged, mourning over a good old man (as he was called by those who had seen

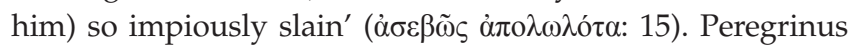
was able to gain his compatriots' praise when he gave to the city all of his father's property. Here Lucian designates these

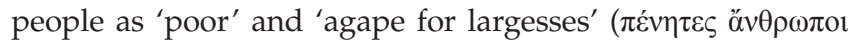

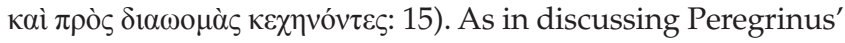
thirst for honour and fame, it is merely the common people, not anyone noble who offers such praise.

Even as he conceeds that Peregrinus did donate his father's property, Lucian attempts to undercut Theaganes' praise for Peregrinus, as he states that all that was left was his father's property worth only 15 talents, and that the entire estate was not worth more than 30, not 5000 as asserted by Theagenes, which is utterly ridiculous. Even the entire city of Parium, taking along with it the five that are its neighbours, would not fetch that much, including the men, the cattle and all the rest of their belongings (14).

In short order, however, Peregrinus runs into financial trouble and attempts to retrieve his father's property, ultimately unsuccessfully (16). One of the virtues for which real men were known, at least since the time of Aristotle, was magnanimity (Asikainen 2018:29-31). By describing Peregrinus as the type who sought to undo his previous generosity toward his hometown, Lucian suggests that he is not magnanimous and only made the 'donation' to ward off the ill will regarding his father's death (15).

Two more factors of Lucian's description are worth mentioning before considering his description of the Christians with whom Peregrinus interacted. Firstly, Peregrinus fell in with Agathobulus, an Egyptian and a Cynic, wherein he began some kind of ascetic practices. The strangeness of the practices (e.g. shaving half of the head, beating one another on the backside with some type of stick: 17) links Peregrinus to marginalised masculinities. The notion that Greeks and Romans were more manly than their neighbours is a rather consistent trope of both Greek and Roman literature (Asikainen 2018:20-23; Lopez 2008:26-55; Williams 2010:148-151). This rhetorical trope may also feature in the description of Peregrinus' adultery as 'in Armenia' (Passing of Peregrinus 9).
In addition, this episode contributes further to the evidence of sexual debauchery treated above (even if we do not consider the taking and receiving of blows on the buttocks as sexual in nature). Lucian tells us that here Peregrinus was 'demonstrating what they [the Cynics] call "indifference"

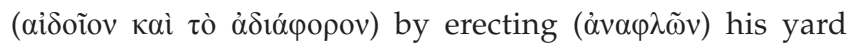
among a thronging mob of bystanders' (17). Harmon's (1972) translation in the Loeb Classical Library obscures a sexual connotation in this passage. The Greek verb ' $\alpha v \alpha \varphi \lambda \tilde{\omega} v^{\prime}$ has to do with masturbation. The English term 'erecting' in Harmon's translation is probably meant to indicate that at the same time it obscures it. Putting together the 'asceticism' of the Egyptians with this type of inappropriate sexual behaviour, masturbation in front of a large crowd of people, clearly effeminates Peregrinus. As we shall see below, there is a parallelism to be observed between the strange (and therefore effeminate) actions of Peregrinus when he goes to Egypt and the actions he undertakes when he is in Palestine.

Finally, it is worth noting that Lucian often makes suggestions that Peregrinus is not as willing to die or as brave as he seems to be. While Peregrinus himself (according to Lucian's account) says of his own death that it is 'to benefit mankind by showing them the way in which one should despise death' (33), Lucian is convinced that he would have skipped his death altogether if the opportunity had presented itself. When Peregrinus had finished his speech just before his death, Lucian tells us: 'he hoped that all would cling to him and not give him over to the fire, but to retain him in life - against his will, naturally' (33). Only a small handful of people (the 'more witless among the people'; $\alpha v o \eta \tau o ́ \tau \varepsilon \rho o r ~ \tau \tilde{\omega} v ~ \alpha ̉ v \theta \rho \omega ́ \pi \omega v$ [33]) asked him to preserve himself, whereas the majority of the crowd told him 'Carry out your purpose!' (33). This crying out from the crowd caused him to turn still paler ( $\dot{\omega} \chi \rho i \tilde{\alpha} v$

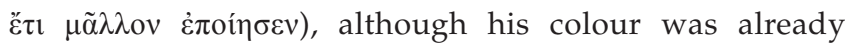

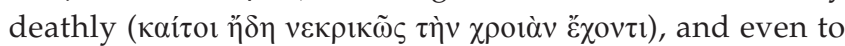
tremble slightly ( $\dot{\pi} \pi \tau \rho \varepsilon \dot{\mu} \mu \varepsilon v$ ), so that he brought his speech to an end (Passing of Peregrinus 33).

Prior to this speech, Lucian had already castigated Peregrinus for choosing a quick method of death (25) and started a rumour that Peregrinus had wanted to change his mind before ever arriving at the games (26). As Williams (2010:151) stresses, in the Roman world 'yielding to the fear of death was held to be a sure sign of effeminacy'.

Toward the very end of the text, after Peregrinus' death, Lucian recounts a time when he and Peregrinus were on a ship together that encountered a significant storm. He says of Peregrinus, 'this wondrous person who was thought superior to death fell wailing along with the women!' (43). Peregrinus' lack of conviction and endurance, together with his 'womanish' display of emotion on the sea, all point to further elements of Lucian's 'unmanning' of Peregrinus. 


\section{Peregrinus and the Christians of Palestine}

The Passing of Peregrinus is most notable, at least in terms of scholarly attention, because it describes Peregrinus' relationship with a Christian community in Palestine (Jones 1986:117). 'It was then that he learned the wondrous lore of the Christians' ( Peregrinus met with 'their priests and scribes in Palestine' (11). Bremmer says the occurrence of these titles together (not attested elsewhere in 2nd-century Christianity) 'strongly suggests that Peregrinus had joined one of the JudaeoChristian congregations that existed, not surprisingly, in Palestine and Syria' (2007:731). More significantly, Lucian reports that 'in a trice, he made them all look like children'

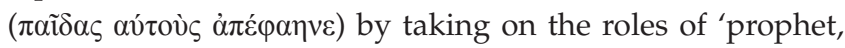

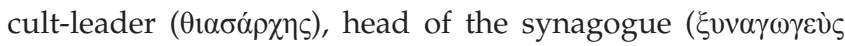
[sic]), and everything, all by himself' (11). This is a significant point for Lucian's understanding of the Christians. He has already made clear that Peregrinus is no kind of man, unable to control himself sexually or in terms of the piety and reverence because of his father. In this case, however, Peregrinus demonstrates control over others. He is able to turn the priests and scribes of the Christians into 'children' by dominating them with his leadership among them. These Christian leaders and their community:

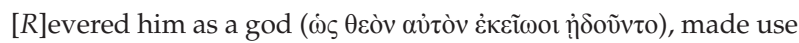
of him as a lawgiver ( ( $\pi \rho \circ \sigma \tau \alpha \dot{\tau \eta} v)$, next after that other, to be sure, whom they still worship, the man who was crucified in Palestine because

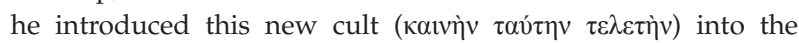
world. (Passing of Peregrinus 11)

\section{Bremmer (2007) rightly notes that it is:}

[A]bsolutely unthinkable that a Christian community could have worshipped Peregrinus as a god' (2007:733) and argues that this appellation is better understood in the same way that other philosophers 'attracted the term "divine" over time'. (pp. 733-734)

Even this understanding seems like a stretch for actual Christians in the 2nd century, and it is more probably hyperbolic vitriol on Lucian's part.

Sections 12-13 of the text summarise Peregrinus' imprisonment and the subsequent reaction of his Christian community. Firstly, his imprisonment 'gave him no little reputation as an asset for his charlatanism and notoriety-

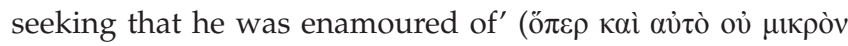

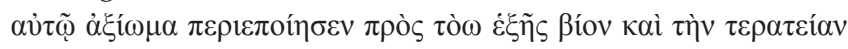

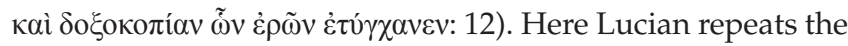
accusation that Peregrinus is motivated by a thirst for glory and notoriety. The Christians mobilised, and unable to get him released from prison:

[F]rom the very break of day aged widows and orphan children

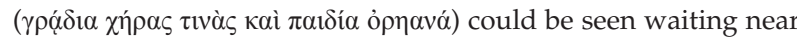
the prison, while their officials even slept inside with him after bribing the guards. Then elaborate meals were brought in, and sacred books of theirs were read aloud, and excellent
Peregrinus - for he still went by that name - was called by them 'the new Socrates'. (Passing of Peregrinus 12)

Other Christians arrived from the cities of Asia, eager to support Peregrinus from their common fund (13). In Lucian's view, all of this support had the consequence not of making Peregrinus more honourable but making him rich: 'he procured not a little revenue from it' (13).

Lucian goes on to describe two characteristics of Christians:

The poor wretches have convinced themselves, first and foremost, that they are going to be immortal and live for all time, in consequence of which they despise death and even willingly give themselves into custody, most of them. (Passing of Peregrinus 13)

One interesting element of this description is that, in the very next section of the text, Lucian says the governor of Syria as 'aware of his recklessness and that he would gladly die in

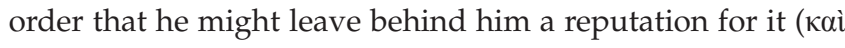

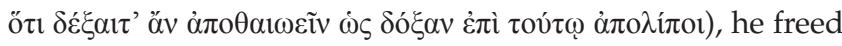
him' (14). Because, as was discussed above, later in the text, Lucian cast aspersions on Peregrinus' bravery and endurance in the face of death, it is an open question whether Lucian thinks that Peregrinus' time with the Christians made him more willing to face death. If so, it undercuts one aspect of Lucian's characterisation of Peregrinus to some extent. Secondly, Lucian says that the 'first lawgiver' of the Christians (by whom he clearly means Jesus):

$[P]$ ersuaded them that they are all brothers of one another after they have transgressed once for all by denying the Greek gods and by worshipping the crucified sophist himself and living under his laws. (Passing of Peregrinus 13)

It is for this reason that 'they despise all things indiscriminately and consider them common property' (13). This notion leads to another critique of Christianity from Lucian: ' $[s] \mathrm{o}$ if any charlatan and trickster, able to profit by occasions, comes among them, he quickly acquires sudden wealth by imposing

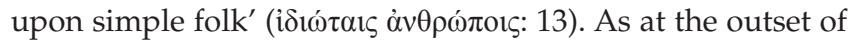
his description of the Christians, so here Lucian concludes by lumping them into the category of simpletons. They are easily duped and, for that reason, their praise is not worth having. But, if they follow an obviously unmanly charlatan like Peregrinus, clearly they do not demonstrate masculine virtue themselves. Lucian's description of these Christians lumps them together with the common folk described elsewhere in the text who offer praise and honour to Peregrinus. Linking such gullible folks, who are most appropriately linked to women and children, allows Lucian to use them further to unman Peregrinus.

According to Lucian's account, Peregrinus' relationship with the Christians comes to an inglorious end when 'after he had transgressed in some way against them - he was seen, I think, eating some of the food that is forbidden to them - they no longer accepted him' (16). This indulgence of forbidden food is yet another way that Lucian characterises Peregrinus as unable to exhibit self-control. To be sure, Lucian does not 
think that the Christian group's refusal to eat whatever type of food may be at issue here is reasonable (on the possibilities for the nature of the prohibited food, see Jones 1986:743-744), but he suggests that his lack of control in this regard is the very thing that sees him expelled from the group.

There is one other way in which Lucian uses the story of Peregrinus to reveal Christians' gullibility.

Lucian claims to be the inventor of tales regarding appearances by Peregrinus after his death. Meeting people coming out to see Peregrinus, expecting him to still be alive, Lucian informs them that he had already thrown himself into the fire (39). Whenever he encountered 'a man of taste', he would relay the story without embellishment:

[B] ut for the benefit of the dullards, agog to listen, I would thicken the plot a bit on my own account, saying that when the pyre was kindled and Proteus had flung himself bodily in, a great earthquake first took place, accompanied by a bellowing of the ground, and then a vulture, flying up out of the midst of the flames, went off to Heaven, saying, in human speech, with a loud voice, 'I am through with the earth; to Olympus I fare'. (Passing of Peregrinus 39)

Lucian notes that these gullible folks believed his made up stories. In fact, in answer to questions they asked, 'I made them whatever reply occurred to me' (39). When Lucian returned to the site of the festival, however, a 'grey-haired

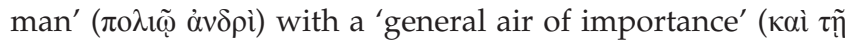
$\lambda$ oı $๊ \tilde{n} \sigma \varepsilon \mu v o ́ v \eta \tau \imath)$ told Lucian a story about Peregrinus appearing in a white garment and wearing a crown from an olive tree (40).

Moreover, he told Lucian 'he himself had seen it [the vulture] flying out of the top of the pyre, when I myself had just previously let it fly to ridicule fools and dullards' ( $\tau \tilde{\omega} v$

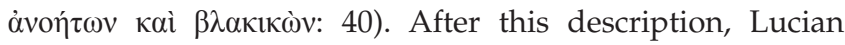
predicts that cultic rites will be made in his honour and statues of him will be made in many cities. König is clear that there are allusions to classical texts in the descriptions that Lucian provides, but he does not preclude influence from Christian tales about Jesus influencing these stories either.

The significant point for this analysis is that gullibility characterises even those who seem to be people of importance when it comes to believing tales made up in light of a hero's death. This perspective helps to explain both why Lucian suggests that the Palestinian Christians might begin to worship Peregrinus and why he understands Jesus to be worshipped for having introduced a 'new cult into the world' (11). Lucian's larger point here is that gullibility with respect to stories of dead charlatans (a category in which he would include both Jesus and Peregrinus) can influence not only the masses, but also those who should know better.

\section{Conclusion}

The chief complaints that Lucian raises against Peregrinus regard the lack of self-control that characterises philosophers and martyrs. Peregrinus is too interested in the honour of the masses as opposed to the honour of other philosophers; he does not exhibit self-control in relation to sexuality or to food consumption at key moments in his life, and he displays a lack of magnanimity. For Lucian, Peregrinus is not a man. He is subject to passions that prevent him from displaying the fearlessness necessary for a proper display of masculinity. In accepting him as a leader in their community, the Christians of Palestine demonstrate that they, too, lack the qualities of masculinity according to Roman codes. Peregrinus is able to bamboozle them into following his teachings and to providing material support for him both inside and outside of Roman custody.

Most significantly, he makes their leaders into 'children' and is attended to by 'women and children' while he is in custody. These accusations against Christians might have some support in historical reality (Jones 1986:736), but they also form part of a pattern of slander against early Christians relating to their lack of masculine virtue (MacDonald 2003:157-162). Lucian's linking of Peregrinus to the Christians tells us less about the Christians than it does about Lucian's efforts to unman Peregrinus. Linking him to Christians aids in this unmanning for his 2nd-century audience.

However, we think about the masculinity of Christians; it is clear that Podles' work on the feminisation of the church represents an ancient, rather than a modern, species of rhetoric. Whether we should be concerned about male participation in Christianity then or now probably depends to a significant extent on how we define 'masculinity' and whether we think hegemonic masculinity is a good and noble, or deeply troubling, enactment of the virtues represented by Jesus.

\section{Acknowledgements}

My thanks to Zeba A. Crook for reading and commenting on an earlier draft of this paper.

\section{Competing interests}

The author has declared that no competing interests exist.

\section{Author(s) contributions}

I declare that I am the sole author of this research article.

\section{Funding information}

This research received no specific grant from any funding agency in the public, commercial or not-for-profit sectors.

\section{Data availability statement}

Data sharing is not applicable to this article as no new data were created or analysed in this study. 


\section{Disclaimer}

The views and opinions expressed in this article are those of the author and do not necessarily reflect the official policy or position of any affiliated agency of the author.

\section{References}

Asikainen, S., 2018, Jesus and other men: Ideal masculinities in the Synoptic Gospels, Biblical Interpretation 159, Brill, Leiden.

Bremmer, J.N., 2007, 'Perergrinus' Christian career', in A. Hilhorst, É. Puech \& E. Tigchelaar (eds.), Flores Florentino: Dead Sea Scrolls and other early Jewish studies in honour of Florentino García Martinez, JSJS 122, pp. 729-49, Brill, Leiden.

Carrigan, T., Connell, B. \& Lee, J., 1985, 'Toward a new sociology of masculinity', Theory \& Society 14(5), 551-604. https://doi.org/10.1007/BF00160017

Cobb, L.S., 2012, Dying to be men: Gender and language in Early Christian martyr texts, Columbia University Press, New York.

Cobb, L.S., 2014, 'Polycarp's cup: Imitatio in the Martyrdom of Polycarp', Journal of Religious History 38(2), 224-240. https://doi.org/10.1111/1467-9809.12008

Connell, R.W., 2005, Masculinities, 2nd edn., University of California Press, Berkeley, CA.

Connell, R.W. \& Messerschmidt, J.W., 2005, 'Hegemonic masculinity: Rethinking the concept', Gender and Society 19(6), 829-859. https://doi.org/10.1177/ 0891243205278639

Conway, C., 2008, Behold the man: Jesus and Greco-Roman masculinity, Oxford University Press, Oxford.

Conway, C.M., 2017, 'Taking the measure of masculinities in Acts', in E.D. Barreto M.L. Skinner \& S. Walton (eds.), Reading acts in the discourses of masculinity and politics, T \& T Clark Library of New Testament Studies 559, pp. 17-27, Bloomsbury, London.

D’Angelo, M.R., 2003, “"Knowing how to preside over his own household”: Imperial masculinity and Christian asceticism in the Pastorals, Hermas, and Luke-Acts', in S.D. Moore \& J.C. Anderson (eds.), New Testament masculinities, Semeia Studies 45, pp. 265-295, Society of Biblical Literature, Atlanta, GA.

Downing, F.G., 1999, “'Honor” among Exegetes', Catholic Biblical Quarterly 61(1) 53-73.

Glancy, J.A., 2003, 'Protocols of masculinity in the pastoral epistles', in S.D. Moore \& J.C. Anderson (eds.). New Testament masculinities, Semeia Studies 45, pp. 235-264, Society of Biblical Literature, Atlanta, GA.

Gleason, M.W., 2003, 'By whose standards (if anybody's) was Jesus a real man', in S.D. Moore \& J.C. Anderson (eds.), New Testament masculinities, Semeia Studies 45 , pp. 325-327, Society of Biblical Literature, Atlanta, GA.
Harmon, A.M. (trans.), 1972, Lucian, 8 vols., Loeb Classical Library, Harvard University Press, Cambridge, MA

Jones, C.P., 1986, Culture and society in Lucian, Harvard University Press, Cambridge, MA

König, J., 2006, 'The Cynic and Christian lives of Lucian's Peregrinus', in K. Sidwell \& J. Mossman (eds.), The limits of ancient biography, pp. 227-254. Classical Press of Wales, Swansea, UK.

Levy, D.P., 2007, 'Hegemonic masculinity', in M. Flood, J.K. Gardiner, B. Pease \& K. Pringle (eds.), International Encyclopedia of men and masculinities, pp. 253255, Routledge, London, UK.

Lopez, D.C., 2008, Apostle to the conquered: Reimagining Paul's mission, Fortress Press, Minneapolis, MN.

MacDonald, M.Y., 2003, 'Was Celsus right? The role of women in the expansion of Christianity', in D.L. Balch \& C. Osiek (eds.), Early Christian families in context: An interdisciplinary dialogue, pp. 157-184. Eerdmans, Grand Rapids, MI.

Moore, S.D. \& Anderson, J.C., 1998, 'Taking it like a man: Masculinity in 4 Maccabees', Journal of Biblical Literature 117(2), 249-273. https://doi.org/10.2307/3266982

Parker, H.N., 1997, 'The teratogenic grid', in J.P. Hallett \& M.B. Skinner (eds.), Roman sexualities, pp. 47-65, Princeton University Press, Princeton, NJ.

Podles, L.J., 1999, The church impotent: The feminization of Christianity, Spence Publishing, Dallas, TX.

Richlin, A., 2007, 'History, ancient Mediterranean civilizations', in M. Flood J.K. Gardiner, B. Pease \& K. Pringle (eds.), International Encyclopedia of men and masculinities, pp. 265-269, Routledge, London.

Stewart, E.C., 2015, 'Sending a boy to do a man's job: Hegemonic masculinity and the "boy" Jesus in the Infancy Gospel of Thomas', Hervormde Teologiese Studies 71(1), 1-9. https://doi.org/10.4102/hts.v71i1.2817

Stewart, E.C., 2016a, 'BTB reader's guide: Masculinity in the New Testament', Biblical Theology Bulletin 46(2), 91-102. https://doi.org/10.1177/0146107916639211

Stewart, E.C., 2016b, 'We'll make a man out of you yet: The masculinity of Peter in the acts of the Apostles', Hervormde Teologies Studies 72(4), 1-7. https://doi org/10.4102/hts.v72i4.3433

Stewart, E.C., 2018, 'Men and masculinity in the New Testament', in C.R. Matthews (ed.), Oxford bibliographies in biblical studies, n.p., Oxford University Press, New York, viewed 17 October 2019, from http://www.oxfordbibliographies. com/abstract/document/obo-9780195393361/obo-9780195393361-0256.xml? skey=hh3Gft\&result=1\&q=eric+stewart\#firstMatch

Walters, J., 1997, 'Invading the Roman body: Manliness and impenetrability in Roman thought', in J.P. Hallett \& M.B. Skinner (eds.), Roman sexualities, pp. 29-43, Princeton University Press, Princeton, NJ.

Williams, C.A., 2010, Roman homosexuality, 2nd edn., Oxford University Press, Oxford.

Wilson, B.E., 2017, 'Contextualizing masculinities in the Book of Acts: Peter and Paul as test cases', in E.D. Barreto, M.L. Skinner \& S. Walton (eds.), Reading Acts in the discourses of masculinity and politics, T \& T Clark Library of New Testament Studies 559, pp. 28-48, Bloomsbury, London, UK. 